Ивана Кочевски

Универзитет у Београду Филолошки факултет

Катедра за славистику

ivana.kocevski@fil.bg.ac.rs
УДК 821.162.3.09

https://doi.org/10.18485/slavistika.2018.22.2.25

оригинални научни рад

примљено 10.02.2018.

прихваћено за штампу 04.10.2018.

\title{
ПОЕТИКА ПРОСТОРА У ТЕОРИЈИ КЬИЖЕВНОСТИ ДАНИЈЕЛЕ ХОДРОВЕ
}

Студија настоји да представи примарно интересовање еминентне чешке теоретичарке књижевности, Данијеле Ходрове, за истраживање појма простора у вези са којим је написала неколико веома значајних дела, попут обимне монографије о простору града - Citlivé město, и неколицину других књига. Осим теоријског рада, обележеног ауторкиним радом у Институту за чешку књижевност Чешке академије, Ходрова је написала и неколико романа. Као веома плодна списатељица, становишта изнесена у бројним студијама она примењује на текстове својих романа, што је у овом раду било илустровано. Осим тога, словенске међукултурне везе препознају се у интересовању Ходрове за есејистичка размишљања чувеног српског архитекте - Богдана Богдановића, кога у свом раду често цитира.

Кључне речи: чешка књижевност, Данијела Ходрова, простор, текст града, градски текст, Праг.

This paper tries to present the primary preoccupation of an eminent Czech literary theorist Daniela Hodrová, to explore the concept of space, about which she wrote several very important works, such as the comprehensive study about space - Citlivé město, and a few other books. In addition to her theoretical work, marked by Hodrova's engagement in the Institute of Czech Literature of the Czech Academy of Sciences, Hodrová has written several novels. As a very prolific writer, she has applied her theoretical thinking in her novels, which was illustrated in this paper. Furthermore, the Slavic intercultural ties are recognized in Hodrová's interest in essays of the famous Serbian architect - Bogdan Bogdanović, whom she often quotes in her work.

Key words: Czech literature, Daniela Hodrová, space, text of a city, city text, Prague.

Данијела Ходрова (Daniela Hodrová, poђ. 1946) је савремена чешка списатељица и теоретичарка књижевности која ради у Институту за књижевност Чешке академије наука. Чешка књижевна критика је смешта у групу аутора такозваног „украденог доживљаја“ у које, између осталог, сврставају и књижевнике чија су дела преведена на српски језик, попут Јиржија Кратохвила и Михала Ајваза. Заједничка карактеристика прозе наведених књижевника је коришћење елемената магијског реализма, као и интертекстуалност борхесовског типа, што се огледа у начину којим се граде књижевни ликови и описује романескни простор. Црте надреализма које се притом у романима ових писаца појављују, односе се на одсуство линеарног приповедања, коришћење фантастичних мотива, колажно слагање различитих приповедних сцена, субјективно представљање догађаја који најчешће подсећају на кошмарне снове. Међутим, Ајваз и Ходрова деле још једну додирну тачку, а то је интересовање за представљање простора родног града - Прага. Концепт просторности у поетици романа код Ајваза је најчешће изграђен кроз дијалектику унутрашњег и спољашњег простора, док је код Ходрове доживљај простора увек представљен кроз узајамно прожимање субјективног искуства са колективним сећањем. Праг се у прози обоје аутора

Славистика XXII/2 (2018) 
често појављује и као ентитет за себе, он постаје живи организам који приповедачки субјект спознаје и описује.

Интересовање за истраживање и представљање појма простора у књижевности није никаква новина. Разматрајући широк спектар различитих области које се, било примарно или секундарно баве истраживањем простоpa, Јосип Ужаревић констатује да није тешко разумети зашто до данашњег дана не постоји свеобухватна, интегрална наука о простору (спејсологија). Један од важних разлога те „необухватљивости“ простора јесте и његова „многоликост“, тј. непрегледно мноштво лица којима се простор окреће истраживачкој свести (Užarević 2011: 9).

Колико је истраживање и представљање простора (нарочито урбане средине) важно у креативном, али и научно-истраживачком раду Данијеле Ходрове, сведоче њени романи у којима јунаци живе у Прагу или је Праг често „главни јунак“ приповести. У питању је најпре трилогија под називом Trýznivé město (Мучан град) која обухвата романе - Kukly, Podobojí и Théta (Лутке, У оба начина и Tema $)^{1}$, потом књига есејистичке прозе Město vidím (Видим град, 1992), али и теоријски радови попут обимне студије Citlivé město (Осећајни град, 2006), избора есеја уврштених у књигу Poetika míst (Поетика места, 1997), као и теоријска књига Mista s tajemstvím (Mesta sa tajnom, 1994).

Простор као и сама идеја просторности, тема је приказа различитих уметности, као и предмет истраживања различитих наука, те стога у различитим видовима уметности као и у различитим књижевним врстама (драми, роману и сл.), постоје различити типови простора, при чему сваки аутор и свако његово дело представљају специфичан модел света. Ходрова на основу оваквих увида закључује, да писац у делу гради свој властити простор, али од оних могућности које му нуди „простор“ времена у коме са̂м живи. Управо на овом месту могу да се препознају трагови онога што Женет разликује као постојање колективног топоса у односу на лични топос који обухвата субјективна искуства и доживљаје неког места оног аутора који о њима извештава.

У теоријским истраживањима простора, Ходрова најпре обраћа пажњу на поетику посебних места у простору. У вези са тим је настао избор есеја више аутора у књизи Poetika mist, у коме Ходрова засебно представља топос собе, куле и затвора. Независно од ових студија из области књижевне тематологије и топологије, у својој обимној студији Citlivé město, Ходрова анализира начин којим се у текст града уписује у књижевни текст, а у вези са чиме се препознаје настанак узајамног утицаја урбаног и књижевног кода.

Овде је реч о поетици простора како у књижевном, тако и у теоријском раду Данијеле Ходрове при чему град постаје кључна реч и доминанта. Град посматран и тумачен као биће за себе, постаје град-личност, који Ходрова тумачи као добро читљив текст који становник или читалац може да разуме, и који својим ходом може да чита тај текст, као и да учествује у њему својим заузимањем простора или становањем (Hodrová 2005: 17-18). У анализи простора аутор-

${ }^{1}$ Сва три наведена романа су била засебно објављена током 1991. године. Књига Мучан град која садржи наведену трилогију, првобитно је била објављена 1999. године, док је њено поновљено издање из 2017. 
ка се користи појмовима као што су текст града и градски текст. Под синтагмом текст града требало би разумети укупан текст који обухвата све врсте текстова у којима је „исписан“ унутрашњи и спољашњи град; под овим се, наравно, подразумева архитектура, али и ликовни, филмски, књижевни и други текстови о граду (самим тим и другачији семиотички системи), потом се овде убрајају „живљени“ текстови, односно субјективна искуства становника града, начин њихове егзистенције и томе слично. Док се под синтагмом градски текст, подразумевају књижевна дела писана у (конкретном) граду или о граду. У вези са тумачењем ове две синтагме - текст града и градски текст, јасно је зашто ауторка спомиње узајамност урбаног и књижевног кода.

У теорији књижевности Ходрова град посматра као текст, односно као знаковни систем; град постаје текст састављен, не само из бесконачних знакова, већ и од многих других текстова и многих знаковних система. Тумачен поменутим теоријским становиштима, град подсећа на недовршену књигу чији се текстови, како Ходрова примећује, уврштавају у целину текстова-градова једне земље, па и самога света (исто: 22). Они су писани, изграђивани, приповедани као реплике на друге текстове-градове, иако се текст града исписује у веома дугом временском распону током кога град понекад не реагује само на друге градове већ и на сопствени рукопис, на сопствене текстове које преписује, у вези са чиме настају урбани палимпсести.

У оквиру тематике у којој се град посматра као својеврстан текст исписан разноврсним семиотичким системима, препознају се везе Ходрове и српског архитекте Богдана Богдановића у вези са интересовањем чешке списатељице за есејистички рад чувеног српског архитекте. Наиме, Ходрова се у свом истраживању позива на поједина становишта Богдановића изречена у делу које је на словачком језику било објављено током 2002. године под називом Mesto a démoni (Град и демони) $)^{2}$ у коме чувени српски архитекта проналази повезаност између града и писма. Како Ходрова примећује, Богдановић прориче тамну будућност града, јер каже да нам је свима потребна уметност „читања“ града да бисмо се приближили конкретној будућој уметности друштвеног, колективног

${ }^{2}$ Богдановићево дело под називом Mesto a démoni објавила је издавачка кућа Ivan Štefánik 2002. године у Братислави. У резимеу ове књиге наводи се да она по први пут излази на словачком језику и да се састоји из две Богдановићеве књиге (није прецизирано које две књиге су у питању) од којих ниједна до тада није била објављена на српском језику. Већ 2005. године исто издаваштво из Братиславе објавило је нову Богдановићеву књигу под називом Sprievodca labyrintom mesta, чија је промоција била одржана у Моцартовој сали Аустријске амбасаде у Братислави (6. октобра 2005). Преводиоци прве књиге су били Карол Хмел (Karol Chmel) и Томаш Человски (Tomáš Čelovský), док је Человски потписао превод и друге књиге. У поговору Sprievodca labyrintom mesta професор Штефан Шлахта (Štefan Šlachta) каже: „Друга књига Богдана Богдановића коју добијамо у руке на словачком језику, представља симбол да смо схватили колико је важно познавање размишљања овог изванредног архитекте, урбанисте и филозофа за нашу садашњост и будућност. Богдан Богдановић је човек кога једни воле а други дубоко мрзе. Међутим, сви без разлике изговарају његово име са бојазношћу и поштовањем... Речник неимара је избор кратких текстова који се крећу на различитим равнима - историјским, географским, књижевним и филозофским. Заједнички именилац је пак увек град - град као живи организам, као урбана и социјална структура, као саставни део предела и као њена супротност“.

(извор цитираног текста: https://www.martinus.sk/?uItem=32863\#description, превод ауторски). 
писања градова. Оно што Ходрова цитира, пронашли смо да Богдановић пише у књизи Град и смрт у којој о писању градова још каже: „Била је то одвајкада дивна мајсторија и велико људско право. Мајсторија је заборављена, а право скоро сасвим изгубљено“ (Bogdanović 1994: 23).

Требало би напоменути да за разлику од градског текста, у књижевном тексту град никада није неутрална позадина (амбијент). Ходрова наглашава да се он појављује као „сабирајући симбол конкретне структуре живота, људских односа“", и може да постане симбол пакла, узалудности и мучења духа, народног или субјективног живота. Однос између текста града и књижевног текста манифестује се, с једне стране припајањем алегоријских фигура на прочеље куће, доживљавањем фасаде као текста, именовањем улица, а са друге стране - урбанизацијом књижевног текста (на пример када се јавља полиперспективизам у приповедању садржаја романа). Управо на овом месту треба истаћи и наративну структуру градског текста, јер су по Ходровој за градски текст карактеристична два начина његовог развијања - струјом и ткањем (односно упредањем). Ауторка у наставку доводи у везу ова два начина приповедања са две праосновне људске делатности - где она линеарно приповедање које се посматра као један ток или струја, описује као орање код кога се кретањем унапред, истовремено копа бразда; док се циклично приповедање доводи у везу са примарно женском делатношћу - предењем или ткањем. На орању и ткању - које од давнина, како ауторка подвлачи, имају магијски аспект, заснована су два типа градских текстова: текст-ток или бразда и текст-тканина или ткиво. У ова два начина писања и типова текстова, које Ходрова обележава и концептом из древне кинеске филозофије о мушком и женском принципу, од којих је први претежно јанг а други претежно јин текст, покреће се и отвара класична наративна структура (исто: 99).

Када је у питању приповедач у делу, Ходрова објашњава да се само чини, уколико је у питању текст-ток, како субјект ношен струјом приповедања постаје само пуки објект или посредник приповести; овакав приповедач је притом, главни лик приповести, он приповеда или приповедањем ствара властити догађај. У тексту-тканини (ткиву) сусрећемо се са различитим типом субјекта - са субјектом доживљеним као "поље”. За разлику од тока који обично има свој извор, ткиво нема очигледан почетак ни крај. Субјекту “пољу” се не губи идентитет, али постаје компликован, проблематичан. Тежња ка вишедимензионалности која је уочљива у тексту-току, овде је замењена тежњом ка полиперспективизму будући да субјекат може да постане мултисубјект, а са њим се линеарни текст мења у текст-мрежу. Ово је уочљиво, не толико у тексту као у целини, већ више у појединим реченицама у којима се прожимају различите врменске и просторне равни. У упреденом тексту је доста потиснут и маргинализован дијалог.

Илустрације оваквих теоријских становишта се препознају у књижевном делу Ходрове још у њеном првом роману објављеном 1991. године под називом Podoboji. Семантичку структуру текста чини историјска алегорија, где је превладавајући део наратива концентрисан на период око Другог светског рата, све до седамдесетих година 20. века. Међутим, митологија и ранији периоди чешке историје једнако су присутни у роману, почев од мотива везаних за ле- 
генде о планини Блањик и светом Вацлаву, до митске фигуре Беле даме. Јунаци романа живе у Прагу, или су у њему некада живели, а сада њихове несрећне душе не умеју да га напусте. Нарација је испрекидана читавим низом различитих сцена кроз које се прати индивидуална трагична судбина неколицине јунака које повезује једно сабиралиште - Олшанско гробље. Глас приповедача у роману се не чује ни на једном месту, те би приповедачка ситуација одговарала персоналном роману према Штанцловој подели, ${ }^{3}$ док је приметно да је и дијалог прилично редукован.

Праг је локација или простор у коме јунаци живе и за који су вишеструко везани и у осталим романима Данијеле Ходрове. Интересантно је притом, да се као тема кроз та дела често провлачи мотив смрти и мртвих који и даље настављају да живе у Прагу. Надовезујући се на ову чињеницу, фреквентан топос који се у романима Ходрове појављује су, или губилишта, или гробља (Шибењичњи врх или Олшанско гробље). Но, поред могућих митолошких и архетипских образложења и симболике коју би ова два топоса могла да имају, нарочито је значајно социолошко тумачење истих, јер се гробља директно доводе у везу са настанком градова. Луис Мамфорд каже да је разлог за настајање градова, поштовање људи према својим мртвима. „Поштовање што га је први човјек гајио према мртвима, које је већ само по себи доказ о живој машти и сновима, можда је одиграло већу улогу у фиксирању одређеног простора за састајање и напокон трајне насеобине, него сви остали практични разлози (Mumford 1968: 8). Осим тога, Мамфорд подсећа да је град мртвих старији од града живих, и да претходи његовом настанку, те да представља готово срце сваког живог града.

Слично Данијели Ходровој, и Богдан Богдановић ће један део своје приповести посветити амбијенту гробља, ${ }^{4}$ у вези са описом чудног односа који је имао са једном својом пријатељицом која га одводи на гробље на Гардошу. ${ }^{5}$ Коначно, један од првих Богдановићевих пројеката које је радио по поруџбини, било је спомен обележје сефардском гробљу у Београду. Отуда потиче његово

${ }^{3}$ Наиме, у првом роману трилогије Данијеле Ходрове, Podoboji, ишчезава свезнајући приповедач чији би глас на субјективан и свезнајући начин коментарисао догађаје. Међутим, за разлику од Штанцловог одређења персоналног романа, по коме се у персоналној приповедачкој ситуацији приказују само краћи временски периоди, у роману Ходрове у прилици смо да пратимо важне историјске догађаје у чешкој историји почев од средњег века, па све до друге половине 20. века. Захваљујући њиховој промени, списатељица постиже динамику наратива, иако се ништа од поменутих догађаја не коментарише са личног, субјективног становишта. Но, сам избор тематике и „лајтмотивска композиција“ заснована управо на представљању проблематике причешћа у оба вида којим је роман именован, помаже у избегавању монотоније.

${ }^{4}$ Овде је опис гробља и његов помен више био у вези са личном анегдотом, иако је гробље важно у архитектонском стваралаштву Богдана Богдановића будући да се посветио пројектовању меморијалних споменика, кенотафа и некропола о чему пише у делу Уклети неимар.

${ }^{5}$ Богдановићево сећање гробља на Гардошу спомиње се и у вези са једним гробним спомеником који он доводи у вези са књигама Јана грофа Потоцког Le manuscrit trouvé a Saragosse (Рукопис из Cарагосе, 1814), на коју надовезује потом књигу Пола Февала Le ville vampire (Град вампира, 1867). Обе су писане у готичком маниру, мрачног садржаја, где је нарочито интересантан амбијент града потоњег романа где је описан град вампира - Селена који је француски писац сместио негде надомак Гардоша, Земуна и Београда. 
интересовање за кабалу и мистику бројева о чему архитекта каже: „Скроман споменик на сефардском гробљу открио ми је да су у мом новом послу метафоре и алегорије бар исто толико важне колико и у поезији" (Bogdanović 2011: 98).

Мотив гробља је изузетно важан у текстовима Ходрове јер се њиме указује на град мртвих који носе своје индивидуалне приче и деле колективну историју. Описивањем овог топоса, Ходрова заправо успева да у свој херметички текст утка прегршт информација везаних за национални усуд Чешке током читавог двадесетог века. Гробље је у прашким текстовима везано са посебним сусретима и познанствима. У теоријским разматрањима, Ходрова подвлачи да је гробље (костурница) мементо живима, који се на овом месту „са полуиспрекиданим или намерно избрисаним сећањем“, сукобљавају са пролазношћу. У прашким текстовима гробље функционише и мало другачије - као метафора или као алегорија града (народа) у његовим различитим историјским тренуцима (Hodrová 2005: 169).

Једно од поглавља романа Podoboji насловљено је као „Олшанско гробље“ које се обраћа читаоцу у првом лицу као антропоморфно биће, и објашњава да је некада - уместо гробља оно било виноград. Међутим, временом је виноград уступао своју парцелу жртвама куге, где је земља дубоко упила винске сокове који сада мртвима миомиришу; они се од ње опијају, једнако као и људи који ходају по гробљу када отровни сокови крену да испаравају. Ходрова описује људе који ноћу тумарају по гробљу, тражећи спас у празним гробницама у данима погрома Другог светског рата. Фантастична слика „живог мртваца“ који се скрива у гробници, и конекција са анђелима, увеличана је употребом наднаравних елемената у реалном свету, описом како гробови са Олшанског гробља нестају јер се винова лоза шири и преплиће своје чокоте обремењене плодовима, који непрестано сазревају и тешким мирисом опијају и трују господина Турчина (оног који се крије). Он за себе размишља како прво мора да окуси хлеб па тек онда да попије вино, односно грожђе. Управо на овом месту препознаје се симболика наслова романа Podoboji (У оба вида) где се свети сакрамент, или света тајна причешћа, изводи у оба вида (конзумирањем тела Христовог у виду хлеба и његове крви, односно вина).

Ходрова потом приказује скрнављење гробља кроз приказ брања винограда од стране нежељених пробисвета, што заправо представља метафору похаране чешке земље од стране Немаца током Другог светског рата, као и погром Јевреја (оличених у лику господина Турчина који ово име носи како би прикрио властито порекло, али и других јунака попут породице Давидович), да би се ове сцене повезале са још једним важним догађајем који се у Прагу десио после равно тридесет година. Ходрова га опет не именује директно, већ наговештава о чему се ради кроз следеће речи - да су утешне речи господина Клечке о будућности чешке земље (упућене његовом пријатељу господину Турчину) биле демантоване оног дана када „су донели младићево тело из ужарене пећи“. Ово је заправо метафора за демонстративно самозапаљивање Јана Палаха током јануара 1969. године на Вацлавском тргу, након чега списатељица објашњава да његово тело није смело да буде покопано у Прагу, већ да су његови остаци били тајно пренесени у село одакле је он потицао (у село Вшетати). Ова интервенција тајне полиције (премештања посмртних остатака несрећног студента Карловог 
универзитета) на неки начин скрнави личност и акт Јана Палаха, те се може окарактерисати варварским чином, у вези са чиме, Ходрова у свом теоријском раду поново цитира Богдановића. Заправо, она наводи да су напади модерних варвара на градове и гробља по Богдановићу, израз њиховог паничног страха од нагомиланог страног сећања и злих, скривених и неразумљивих порука (Hodrová 2005: 35). Конкретан Богдановићев текст о овој теми проналази се у књизи Град и смрт, где архитекта каже: „Модерни варвари затиру и гробља са истом систематичношћу са којом разарају и градове. А како су и гробља нека врста градова, опет се јавља исти онај панични страх од нагомилане ,туђе' меморије и опаких окултних, неразумљивих порука. При том, рушитељи не знају - одакле би и знали? - да, насрћући на успомене својих ближњих, кидају ланац сопствене антрополошке меморије“ (Bogdanović 1994: 36).

Преплитање становишта чешке списатељице и српског архитекте је уочљиво и на другим местима, како у теоријској студији Citlivé mésto, тако и у роману Podobojí (који цитирамо као илустрацију теоријских становишта Д. Ходрове). У Уклетом неимару Богдан Богдановић у својим субјективним исказима не представља опис самог града, већ пружа занимљив опис куће-дома који за њега постаје скровиште-бункер, и како каже - замало гробница. Феноменолошки посматрано то је затворен простор који се изнутра посматра очима архитекте. Реципрочно томе, код Ходрове њена јунакиња Алице у роману Podobojí, иако мртва, никада не одлази на Олшанско гробље, већ се враћа у властити стан који се налази преко пута тог гробља. У стану обитавају и душе њених бабе и деде, тако да стан уистину постаје пребивалиште мртвих - гробно место.

Тумачење простора града Ходрова и у теоријској студији Citlivé město, и у роману Podobojí, наставља кроз засебан приказ и анализу одређених објеката и институција у граду, као што су на пример храм, музеј, депоније, складишта, позоришта, тргови, скулптуре, али и приказ града одозго, из птичије перспективе, кроз анализу мотива заласка сунца, подземља града и мотива пешачења по граду. Један од најинтересантнијих мотива откривања града је слика Прага као зле мајке. Корени оваквог становишта срећу се и код Мамфорда који каже да су: „Кућа, село, а у крајњој линији и са̂м град, заправо је једна велика жена“ (Mumford 1968: 15) ${ }^{6}$. Ходрова наговештава да се у чешкој књижевности на прелому између 19. и 20. века појављује управо метафора Прага као зле Мајке,

${ }^{6}$ Транформација улоге и функције алегоријске слике Прага у вези је и са древним азијским и грчким божанствима која су утицала на друштвени живот и унутрашњу организацију древних градова. Луис Мамфорд објашњава да се у најстаријим религиозним митовима доминантна женственост манифестовала кроз дивље атрибуте жене којима се упућивало на преузимање особина мушкараца. Поменути атрибути су сачувани у страшном лику хиндуистичке богиње Кали. Најстарије месопотамијско божанство била је богиња Тијамат, првобитна Мајка Вода - непријатељски расположена према својим побуњеним синовима, док је култ Кибеле, Велике Мајке, касније замењен нежнијим мајчинским ликом као што је Деметра - Мајка Жетве. Овакав концепт жене мајке и хранитељке смењен је доминантном улогом мушких божанстава, те су женска божанства сада могла бити концентрисана на мање примитивне аспекте своје сексуалности - на нежност, лепоту, еротско уживање, што је потом отеловљено у ликовима богиња као што су - Иштар, Астарта, Афродита (Mumford 1968: 28). Ова Мамфордова објашњења о функцији и улози женских божанстава древног света, наводимо као илустрацију могућих алегоријских значења Прага. 
њено преобраћање од краљице у посрнулу блудницу, од мајке у маћеху, из представе mater nutrix у представу mater terribilis - као рефлексија губитка личних и колективних илузија (Hodrová 2005: 153). Ово тумачење града као зле мајке унеколико објашњава избор Ходрове да своју трилогију романа именује као Trýznivé тёsto (Град патње или мучеништва).

Још једна занимљива група мотива којима се чита текст града везана је за (полу)скривени бестијар чије поједине животиње и монструми, зелени људи, рогати диониси што се појављују у виду кућевних знамења, маски на фасадама кућа, на канделабрима и слично, представљају јединствен израз колективно несвесног града. То је прашки архетипско-интертекстуални низ мотива, као што су - Голем, Ахасвер, ахати у Сватовацлавској капели, свети Вацлав, Орлој, водорига, гробница краљева, скулптуре на Карловом мосту, различите представе змајева.

Међутим, читава поетика простора града не би била уочљива ни интересантна да није субјекта који би могао да је уочи и истражи. С тим у вези, Ходрова оперише појмом „прашки пешак“ који је недељив саставни део прашког контекста. Говор о граду, или са̂м говор града који се обраћа пешаку, појављује се у фрагментима, као нешто вечито "неодређено". Са̂м град се пешаку-читаоцу јавља као процесуални колаж који прати, и који би требало да дешифрује. Пешачење кроз град није у вези само са типом човека, већ са природом места и карактером пута, објашњава Ходрова. У ходање се углавном уписује немир унутрашњости града, где се у књижевним текстовима корачање често мења у трк, који представља израз мучнине због претеће опасности, од властитог двојника, па и самога града. Било да је ход одлучан или несигуран, са циљем или без њега, он остаје покрет којим се град перципира и субјективно доживљава. Ходрова разликује притом, две врсте хода - свакодневни ход који прати практичан циљ и супротно томе, постоји ход као врста искорачења из свакодневног ритма у сврху истраживања и откривања света, у вези са чиме се препознаје митолошки ход.

Док пише о Прагу у есејистичкој прози Město vidím, Ходрова ствара такозвани текст о Прагу, али осим њеног текста, ту су и текстови других писаца, као и легенде које су о граду вековима настајале и које се кроз генерације препричавају. Управо у два поглавља за редом (под називом „Тváŕ v achátu“ и „Š́́m“), Ходрова интертекстуално преплиће властити текст о Прагу са приповетком Гијома Аполинера „Прашки пролазник“, затим са Мејринковим романом Голем, као и са легендама о вечитом Јеврејину Ахасверу, и оживљавању голема уз помоћ необичног предмета званог шем; овај назив (шем) користи се уместо имена Бога, и значи Име. ${ }^{7}$ Да би се разумела ова констатација Аполинеровог јунака,

7 Аполинерова приповетка, на српски преведена као „Прашки пролазник“, исприповедана је у првом лицу и састоји се делом од аутентичних Аполинерових исказа везаних за његов боравак у Прагу 1902. године, а делом од приповедачке уобразиље. Приповедачу приликом ове посете Прагу случајним сусретом, водич и кратко време сапутник, постаје Јеврејин Луталица - Ахасвер који се овде представља по имену Исак Лакедем. Аполинер описује делове града које обилази за овим необичним прашким пешаком, ту се најпре спомиње Старомјестски трг и Тински храм, затим Старомјестска радњице или Градска кућа на којој се налази чувени прашки астрономски сат; ови „градски путници“ потом настављају свох ход ка јеврејском гробљу и четврти, где се налази синагога, потом прелазе Влтаву преко Карловог моста да би се потом успињали на Храдчане где су обишли замак, а онда и кате- 
довољно је навести тумачење Богдановића који објашњава да град остаје само онда град, када се као град може прочитати и уколико својим карактеристикама исијава унутрашњу, метафизичку енергију. „Наиме прочитати град, значи видети са̂м себе у огледалу“ (Hodrová 2005: 35).

Поетика простора Ходрове присутна је у њеним теоријским размишљањима у вези са топоанализом, митопоетиком града и посебних, како сама каже, „тајанствених места“ у простору постојећег универзума. Осим тога, та поетика се препознаје у њеним романима посвећеним најчешће родном граду, његовим становницима, његовом „сећању“ и дешифровању порука које чува за нове генерације. У романима Ходрове уочљиво изостаје било каква сувисла радња или дијалози, јер је све подређено ауторкином личном читању текста града (у вези са чиме настаје градски текст) који се преплиће са колективним националним искуством и представама. Хронотоп Прага постаје суштински чинилац у конституисању сижеа трилогије романа Tryznivé město, али и есејистичке прозе Město vidím, која се наставља на поменуту трилогију и својим садржајем је допуњује. За Ходрову је сагледавање града увек везано за субјективно реципирање његове историје исписане на улицама, фасадама, крововима, ентеријерима, као и за личну реминисценцију о местима која је некад посетила, и која за њу имају посебно значење; те се и у овој есејистичкој прози, лична историја прожима са историјом родног града списатељице. На овај начин је поетика простора присутна у готово свим видовима књижевног стваралаштва ове чешке књижевнице, али је истовремено и универзално примењива, будући да у читање и тумачење простора у књижевним делима обезбеђује добре упуте шта тачно тражити и на који начин приступати анализи простора. Осим тога, Ходрова упућује на терминологију коју је могуће применити у читању градског текста и других аутора којима је примарна вокација опис урбане средине или представљање просторности уопште. У ту сврху ауторка је у Богдановићевим есејима пронашла размишљања слична својим, пре свега у вези са уверењем да се град може „прочитати“ кроз тумачења његове пластике и орнамената, кроз значења, функцију и намену институција и објеката у њему, кроз историју и конкретне локације, односно места као што је већ било поменуто гробље. У интерпретацији значења ове нарочите врсте писма које представља са̂м град, посматрач-читалац уноси једнако субјективно и колективно искуство. Отуда становиште Богдановића које каже да „прочитати град значи видети самог себе у огледалу“, јер у субјективним тумачењима огледамо властита знања, доживљаје и перцепцију. С друге стране, те поруке које остају у облицима, покретима, бојама, обраћају се свима онима који у годинама након настанка, не само појединих објеката у граду, него целих градских четврти, тргова, улица, паркова, живе или пролазе кроз град, те реципрочно могу о њему сада да размишљају, да пишу и дешифрују његова значења и поруке, или да интервенишу на њиховом изгледу преправљањем или пак потпуним уништењем

дралу светог Вита. Свако од наведених места, притом, обилује културолошким, историјским, митолошким значењима али у чије тумачење, посматрачи уносе властита искуства и личности. Управо у капели светог Вацлава, Лакедем скреће пажњу приповедачу на капелу опточену полудрагим камењем - ахатом и минералима. У игри линија које су се на овим минералима оцртавале, Лакедем је видео Наполеоново лице које је показао приповедачу, а који пак инсистира да у истим линијама препознаје самог себе, као и да је то, заправо, његов портрет. 
(о чему говори Богдановић у прози Град и смрт). Стога се у закључку може нагласити да, поређење размишљања чешке књижевнице и српског архитекте, представља прилог у прегледу словенских међукултурних веза.

\section{Цитирана литература}

Bogdanović, Bogdan. Grad i smrt. Beograd: Beogradski krug, 1994.

Bogdanović, Bogdan. Ukleti neimar. Novi Sad: Mediterran publishing, 2011.

Hodrová, Daniel. Místa s tajemstvím. Praha: Koniasch Latin Press, 1994.

Hodrová, Daniela. Poetika míst. Praha: H\&H, 1997.

Hodrová, Daniela. Citlivé město. Praha: Akropolis, 2006.

Hodrová, Daniela. Město vidím. Červený Kostelec: Pavel Mervart, 2009.

Hodrová, Daniela. Trýznivé město. Praha, 2017.

Mumford, Lewis. Grad u historiji. Zagreb: Naprijed, 1968.

Užarević, Josip. Möbiusova vrpca - Knjiga o prostorima. Beograd, Službeni glasnik, 2011.

\section{Ivana Kočevski}

\section{POETICS OF SPACE IN LITERARY THEORY OF DANIELA HODROVÁ}

\section{Summary}

The importance of the research and representation of space (especially urban areas, most often Prague) in the fiction, but also the scientific research of Daniela Hodrová, can mostly to be seen in a variety of her novels written in Prague or about Prague - such as the trilogy called Trýznivé mésto, but also in a number of theoretical studies, among which the most significant is Citlivé mésto. In the analysis of space Hodrová generally operates with terms such as - "the text of a city" and "a city text". The first refers to a city's architecture, artistic and any other kind of text that exists in an urban area, in a form that contains a particular message or conveys a certain meaning to the observer. The other term refers to all the texts written in a city or about a city. Within the topic in which a city is regarded as a kind of text, produced via various semiotic systems, modern and existing intercultural Slavic ties can be recognized. In fact, Hodrová often cites the views of the famous Serbian architect Bogdan Bogdanović in her research of space, namely those published in a book translated in the Slovak language as Mesto a démoni. Hodrová uses the mentioned terminology very skillfully, showing us that it can be applied in the reading of the city text of other authors, whose literary work primarily refers to an urban environment or the presentation of space in general.

Key words: Czech literature, Daniela Hodrová, space, text of a city, city text, Prague. 